\title{
SISTEM INFORMASI AKREDITASI PROGRAM STUDI BERBASIS WEBSITE
}

\section{(Studi kasus di Prodi Teknik Informatika Universitas Muhammadiyah Tangerang)}

\author{
Yani Sugiyani ${ }^{1}$, Ali Firdaus ${ }^{2}$, Rohmat Taufik ${ }^{3}$, Mayang Agustina ${ }^{4}$ \\ (1), (2), (3), (4) Program Studi Teknik Informatika - Universitas Muhammadiyah Tangerang \\ (1)Yani.sugiyani@gmail.com, , $^{(1)}$ zhafifirdaus@gmail.com, ${ }^{(2)}$ rohmat.taufiq@umt.ac.id,(3) \\ dagustina28maiiank@gmail.com ${ }^{(4)}$
}

\begin{abstract}
Abstrak, Akreditasi merupakan kegiatan penilaian berdasarkan Standar Nasional Pendidikan Tinggi (SNPT) untuk menjamin mutu pendidikan tinggi pada program studi di setiap Perguruan Tinggi di Indonesia. Proses Akreditasi diselenggarakan oleh Badan Akreditasi Nasional Perguruan Tinggi (BAN - PT) dan melibatkan asesor sebagai penilai dan Tim Penyusun (Tim Borang). Penelitian ini dilaksanakan di Universitas Muhmaadiyah Tangerang. Selama ini proses tersebut masih dilakukan secara manual, dan menimbulkan berbagai permasalahan, diantaranya tidak adanya informasi yang tertata dengan rapi yang menyediakan data penyusunan borang akreditasi, sulitnya menentukan waktu untuk para tim penyusun (tim borang) untuk berkumpul serta adanya pencatatan data yang berulang - ulang. Penelitian ini memberikan rancangan konsep dan desain sistem informasi yang dapat membantu otomatisasi proses penyusunan boring akreditasi. Sistem Informasi Akreditasi Teknik Informatika (SiAksi Informatika) ini dirancang berbasis website, sehingga dapat memudahkan pengguna dalam mengakses sistem. SiAksi ini dirancang menggunakan metode SDLC dengan UML Diagram, yaitu Use Case Diagram, Activity, Statechart, dan Sequence Diagram sebagai bahasa pemodelannya. Hasil output dari penelitian ini dibuat sama persis dengan instrument yang telah ditentukan oleh BAN - PT.
\end{abstract}

Kata kunci : akreditasi, sistem informasi, website, SDLC, UML

\section{PENDAHULUAN}

Sistem akreditasi merupakan salah satu bentuk penilaian (evaluasi) mutu dan kelayakan institusi perguruan tinggi atau program studi yang dilakukan oleh organisasi atau badan mandiri di luar perguruan tinggi. Penilaian tersebut digunakan sebagai tolak ukur mutu bagi semua program studi dan intitusi pendidikan tinggi baik dari perguruan tinggi negeri maupun swasta yang menyelenggarakan program professional maupun akademik.

Semakin baik nilai akreditasi akan berdampak pada pandangan pihak luar mengenai kualitas program studi dan institusi pendidikan tinggi tersebut. Proses akreditasi dilakukan dalam periode tertentu dan harus diperbarui paling lambat 6 bulan sebelum masa akreditasi berakhir. Instrumen akreditasi program studi terdiri atas: Borang Program Studi atau Borang IIIA, Evaluasi Diri Program Studi, dan Borang yang diisi oleh Fakultas/ Sekolah Tinggi. Jurusan teknik informatika atau program studi teknik informatika harus dapat menjamin mutu atas penyelenggaraan kegiatan tridharma perguruan tinggi yang dilakukan untuk mencapai peningkatan mutu yang berkelanjutan. Evaluasi mutu program studi dilakukan melalui akreditasi program studi sebagai proses untuk penilaian secara komprehensif atas komitmen program studi terhadap mutu dan kapasitas

Masalah yang sering kali muncul adalah tidak adanya informasi yang tertata dengan rapi yang menyediakan data penyusunan borang akreditasi. Padahal program studi di perguruan tinggi setiap periode waktu tertentu misalnya 3 atau 5 tahun mengajukan akreditasi program studi. Jika tidak ada sebuah data center (sumber data) yang dapat dimanajemen secara periodik, maka pencatatan akan terjadi berulang-ulang, padahal informasi sebelumnya sangat berguna pada penyusunan borang akreditasi selanjutnya. Serta untuk pengumpulan data dan informasi serta pengisian borang pada program studi teknik informatika masih dilakukan secara manual yaitu berupa berkas word dan pada saat pengisian borang para tim penyusun mengalami 
kesulitan untuk dapat berkumpul pada waktu yang sama.

Oleh karena itu, sebuah sistem informasi berbasis website sangat diperlukan sebagai sarana untuk menampung dan menyimpan serta menampilkan informasi mengenai program studi. Sistem informasi borang akreditasi program studi teknik informatika ini dibuat dengan sistem terintegrasi dengan aplikasi web sebagai media interaktif dan database sebagai media penyimpanan data. Aplikasi web dan database ini dapat dijadikan template untuk menggambarkan kinerja suatu program studi dan dapat dimanfaatkan untuk mendokumentasikan kondisi internal untuk kebutuhan proses akreditasi program studi.

Penelitian ini penting untuk dilakukan, karena sangat membantu mengurangi pencatatan data yang berulang-ulang dalam penyusunan borang akreditasi serta dapat mempercepat proses penyusunan borang akreditasi. Penelitian ini di beri judul "Sistem Informasi Akreditasi Program Studi Berbasis Website" (Studi kasus di Prodi Teknik Informatika Universitas Muhammadiyah Tangerang).

\section{LANDASAN TEORI}

\section{A. Definisi Borang}

Menurut Tantra dalam Chandra, dkk, borang adalah alat untuk mengumpulkan dan mengungkapkan data dan informasi yang digunakan untuk menilai kelayakan dan mutu institusi perguruan tinggi.

Borang merupakan instrumen akreditasi yang berupa formulir yang berisikan data dan informasi yang digunakan untuk mengevaluasi dan menilai mutu suatu program studi tingkat program sarjana dan diploma

\section{B. Akreditasi Program Studi Sarjana}

Akreditasi program studi sarjana adalah proses evaluasi dan penilaian secara komprehensif atas komitmen program studi terhadap mutu dan kapasitas penyelenggaraan program tridarma perguruan tinggi, untuk menentukan kelayakan program akademiknya. Evaluasi dan penilaian dalam rangka akreditasi program studi dilakukan oleh tim asesor yang terdiri atas pakar sejawat dan/atau pakar yang memahami penyelenggaraan program akademik program studi. Keputusan mengenai mutu didasarkan pada evaluasi dan penilaian terhadap berbagai bukti yang terkait dengan standar yang ditetapkan dan berdasarkan nalar dan pertimbangan para pakar sejawat. Buktibukti yang diperlukan termasuk laporan tertulis yang disiapkan oleh program studi yang diakreditasi, diverifikasi dan divalidasi melalui kunjungan atau asesmen lapangan tim asesor ke lokasi program studi.

Standar akreditasi program studi sarjana mencakup standar tentang komitmen program studi sarjana terhadap kapasitas institusional (institutional capacity) dan komitmen terhadap efektivitas program pendidikan (educational effectiveness), yang dikemas dalam tujuh standar akreditasi, yaitu:

- Standar 1. Visi, misi, tujuan dan sasaran, serta strategi pencapaian.

- Standar 2. Tata pamong, kepemimpinan, sistem pengelolaan, dan penjaminan mutu.

- Standar 3. Mahasiswa dan lulusan.

- Standar 4. Sumber daya manusia

- Standar 5. Kurikulum, pembelajaran, dan suasana akademik.

- Standar 6. Pembiayaan, sarana dan prasarana, serta sistem informasi.

- Standar7. Penelitian dan pelayanan/pengabdian kepada masyarakat, dan kerja sama.

Asesmen kinerja program studi sarjana didasarkan pada pemenuhan tuntutan standar akreditasi. Dokumen akreditasi program studi sarjana yang dapat diproses harus telah memenuhi persyaratan awal (eligibilitas) yang ditandai dengan adanya izin yang sah dan berlaku dalam penyelenggaraan program studi sarjana dari pejabat yang berwenang; memiliki anggaran dasar dan anggaran rumah tangga/statuta dan dokumen-dokumen rencana strategis atau rencana induk pengembangan yang menunjukkan dengan jelas visi, misi, tujuan dan sasaran program studi sarjana; nilai-nilai dasar yang dianut dan berbagai aspek mengenai organisasi dan pengelolaan program studi sarjana, proses pengambilan keputusan penyelenggaraan program, dan sistem jaminan mutu.

\section{Pengertian Sistem Informasi}

Menurut Leitch dan Davis dalam Kurniawan dan Arkan (2016), Sistem informasi adalah suatu sistem di dalam suatu organisasi yang 
mempertemukan kebutuhan pengolahan transaksi harian, mendukung operasi, bersifat manajerial dan kegiatan strategi dari suatu organisasi dan menyediakan pihak luar tertentu dengan laporan-laporan yang diperlukan.

Menurut Burch dan Grudnitski dalam Kurniawan dan Arkan (2016), komponen sistem informasi terdiri atas :

1. Block Masukan : data yang masuk ke dalam sistem informasi

2. Block Model : kombinasi prosedur, logika dan model matematika yang akan memanipulasi data dengan cara yang sudah tertentu untuk menghasilkan keluaran yang diinginkan.

3. Block Keluaran : informasi yang dihasilkan.

4. Block Teknologi : humanware atau brainware, software dan hardware

5. Block Basis Data : kumpulan data yang saling berhubungan, tersimpan di perangkat keras komputer dan digunakan perangkat lunak untuk memanipulasinya.

6. Block Kendali : pengendalian sistem informasi agar dapat berjalan sesuai dengan yang diinginkan.

\section{METODE PENELITIAN}

\section{A. Jenis Penelitian}

Dalam penyusunan skripsi ini, peneliti menggunakan jenis dan pendekatan penelitian deskriptif kualitatif dengan tujuan untuk membuat deskripsi atau gambaran secara sistematis, faktual, akurat mengenai faktor faktor, sifat - sifat serta hubungan antara fenomena yang diselidiki.

\section{B. Metode Pengumpulan Data}

Dalam penelitian ini, diperlukan data - data serta informasi yang relatif lengkap sebagai bahan yang dapat mendukung kebenaran materi uraian dan pembahasan. Oleh karena itu, sebelum penyusunan penelitian ini dilakukan, maka dilakukan riset atau penelitian terlebih dahulu untuk menjaring data serta informasi yang terkait. Teknik pengumpulan data yang dilakukan adalah sebagai berikut :

\section{a. Metode Observasi}

Yaitu dengan melakukan pengamatan dan pencatatan secara langsung di Universitas Muhammadiyah Tangerang Program Studi Teknik Informatika untuk melakukan pengamatan dan pencatatan sistem yang berjalan saat ini.

b. Metode Wawancara

Yaitu dengan cara melakukan tanya jawab secara langsung kepada Bapak Mahfud selaku sekretaris program studi yang secara jelas mengetahui permasalahan menyangkut sistem yang diteliti.

c. Metode Pustaka

Yaitu dengan mengumpulkan data dari buku atau bahan tulisan yang ada relevansinya dengan skripsi ini.

\section{Metode Pengembangan Sistem}

Metode Pengembangan Sistem yang peneliti terapkan adalah dengan menggunakan metode SDLC (System Development Life Cycle). Penggunaan metode ini peneliti terapkan karena sangat cocok untuk membuat sistem informasi akreditasi dengan alur dan runtutan yang jelas. Adapun tahap - tahap SDLC sebagai berikut :

1. Reqruitment (Hardware, software)

Requirement atau analisis kebutuhan sistem bertujuan untuk mengetahui teknologi seperti apa yang cocok untuk diterapkan, perangkat keras dan perangkat lunak apa saja yang dibutuhkan, serta siapa saja pengguna yang akan menggunakan sistem ini. Kebutuhan sistem yang diusulkan:

A. Kebutuhan Software

1. Sistem Operasi Windows (7/8/10)

2. Apache (Web Server)

3. PHP

4. $M y S Q L$

B. Kebutuhan Hardware

1. Processor Intel Dual Core keatas atau yang sekelas

2. Minimal RAM $1 \mathrm{~GB}$

3. Monitor atau LCD

4. Keyboard dan Mouse

C. Kebutuhan Fungsional

1. Registrasi, yaitu proses membuat akun.

2. Login, yaitu proses verifikasi pengguna sebelum mengakses menu utama.

3. Profile, digunakan user untuk melihat dan mengedit data akun.

4. Data Prodi, digunakan kaprodi untuk mengedit data identitas program studi. 
5. Data Dosen, digunakan kaprodi untuk menambah, mengedit dan menghapus data dosen program studi.

6. Data Pengisi Borang, digunakan kaprodi untuk melihat data yang bertanggung jawab terhadap isian borang dan kaprodi dapat mengedit hak akses akun tim borang.

7. Data Akreditasi, digunakan sebagai instrument borang akreditasi untuk diinput oleh tim borang.

8. Cetak data identitas program studi, data dosen, data pengisi borang dan borang akreditasi.

\section{Pengguna Sistem (User)}

Sistem informasi akreditasi program studi berbasis web terbagi atas 3 pengguna, yaitu :

1. Admin

Admin dapat menggunakan sistem ini untuk melihat data prodi, data dosen, data pengisi borang, data akreditasi dan dapat mengelola user dan menu.

2. Kaprodi

Kaprodi dapat menggunakan sistem ini untuk kelola data prodi, data dosen, data pengisi borang dan data akreditasi.

3. Tim Borang

Tim borang dapat menggunakan sistem ini untuk melihat dan mencetak data prodi, data pengisi borang, data dosen dan dapat mengedit data akreditasi.

\section{Design (UML \& Database)}

Untuk menggambarkan prosedur dan proses sistem berjalan yang diusulkan oleh penulis, maka penulis akan menjelaskan design UML dari sistem tersebut sebagai berikut :
a. Perancangan Use case Diagram

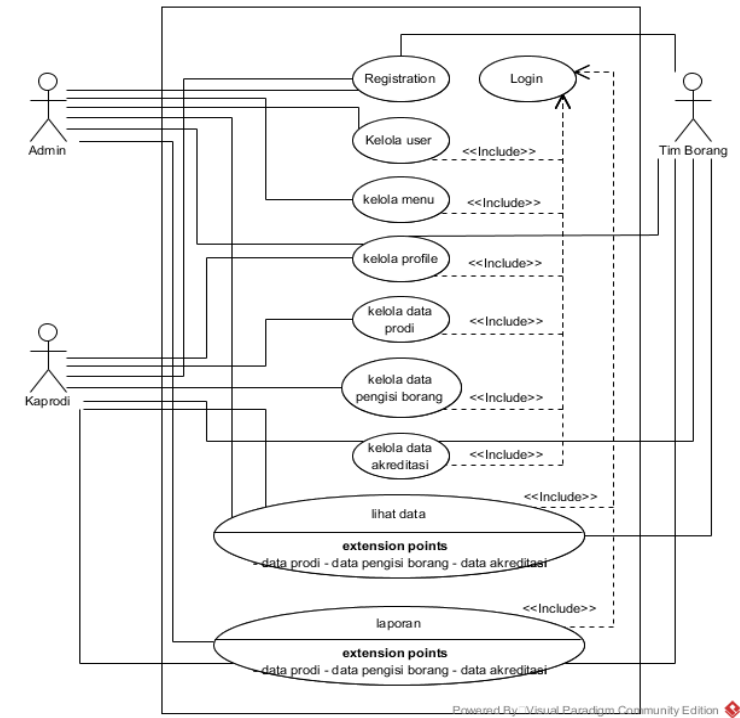

Gambar 1. Use case Diagram

Pada use case ini terdapat 4 aktor, penjelasannya pada tabel 4.2 sebagai berikut:

Tabel 1. Deskripsi Aktor

\begin{tabular}{|l|l|l|}
\hline No. & Aktor & \multicolumn{2}{|c|}{ Penjelasan } \\
\hline 1. & Admin & $\begin{array}{l}\text { Pengguna yang memiliki } \\
\text { hak akses untuk } \\
\text { melakukan pengelolaan } \\
\text { user, menu dan hak } \\
\text { akses setiap user, } \\
\text { mengedit akun, dan dapat } \\
\text { melihat data prodi, data } \\
\text { pengisi borang dan data } \\
\text { dosen, dan data } \\
\text { akreditasi. }\end{array}$ \\
\hline 2. & Kaprodi \\
& $\begin{array}{l}\text { Pengguna sistem yang } \\
\text { dapat menginput, } \\
\text { menambah, mengedit, } \\
\text { menghapus dan } \\
\text { mencetak data prodi, data } \\
\text { dosen, data pengisi } \\
\text { borang dan data } \\
\text { akreditasi, serta dapat } \\
\text { mengubah hak akses tim } \\
\text { pengisi borang dan } \\
\text { mengedit akun. }\end{array}$ \\
\hline 3. & $\begin{array}{l}\text { Pengguna sistem yang } \\
\text { dapat menginput, } \\
\text { menghapus dan } \\
\text { mencetak data akreditasi, }\end{array}$ \\
\hline Borang
\end{tabular}




\begin{tabular}{|l|l|l|}
\hline No. & Aktor & \multicolumn{1}{|c|}{ Penjelasan } \\
\hline & & $\begin{array}{l}\text { melihat data prodi, data } \\
\text { pengisi borang dan data } \\
\text { dosen serta dapat } \\
\text { mengedit akun. }\end{array}$ \\
\hline
\end{tabular}

b. Perancangan Activity Diagram

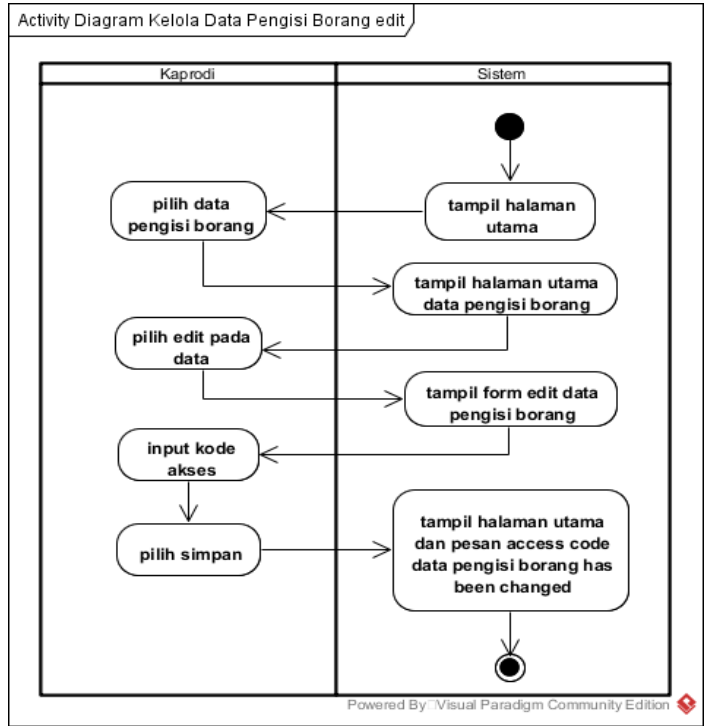

Gambar 2. Activity Diagram

\section{c. Perancangan Sequence Diagram}

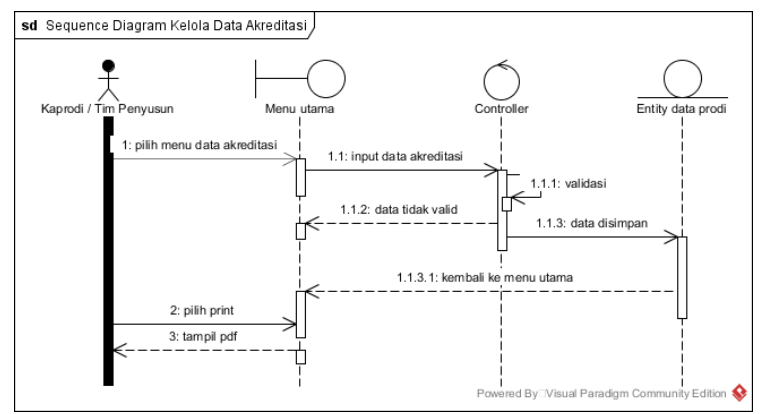

Gambar 3. Sequence Diagram

\section{d. Perancangan State Chart Diagram}

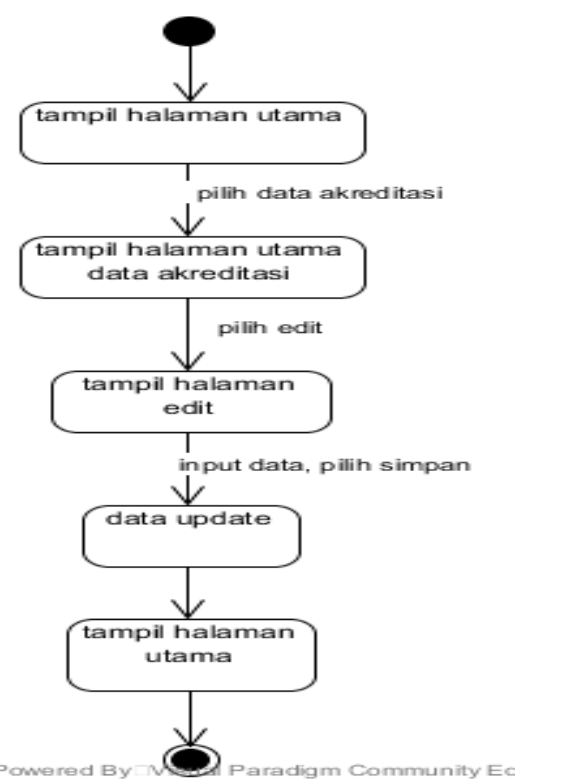

Gambar 4. State Chart Diagram

e. Perancangan Database

1. Tabel User (user)

Tabel 3. Penjelasan Tabel user

\begin{tabular}{|c|l|l|c|}
\hline No & \multicolumn{1}{|c|}{ Field } & \multicolumn{1}{|c|}{ Type Data } & Size \\
\hline 1 & Id & Int & \\
\hline 2 & Nama & Varchar & 128 \\
\hline 3 & Nidn & Int & 10 \\
\hline 4 & Jabatan & Varchar & 25 \\
\hline 5 & Email & Varchar & 128 \\
\hline 6 & Image & Varchar & 128 \\
\hline 7 & Password & Varchar & 256 \\
\hline 8 & Role_id & Int & 11 \\
\hline 9 & Is_active & Int & 1 \\
\hline 10 & Date_created & Int & 11 \\
\hline
\end{tabular}

\section{Tabel User Role (user_role)}

Tabel 4. Penjelasan Tábel user_role

\begin{tabular}{|c|l|l|c|}
\hline No & \multicolumn{1}{|c|}{ Field } & \multicolumn{1}{|c|}{ Type Data } & Size \\
\hline 1 & Id & Int & \\
\hline 2 & Role & Varchar & 128 \\
\hline
\end{tabular}


3. Tabel User Menu (user_menu)

Tabel 5. Penjelasan Tabel user_menu

\begin{tabular}{|c|l|l|c|}
\hline No & \multicolumn{1}{|c|}{ Field } & \multicolumn{1}{|c|}{ Type Data } & Size \\
\hline 1 & Id & Int & \\
\hline 2 & Menu & Varchar & 128 \\
\hline
\end{tabular}

4. Tabel User Access Menu (user_access_menu)

Tabel 6. Penjelasan Tabel user_access_menu

\begin{tabular}{|c|l|l|c|}
\hline No & \multicolumn{1}{|c|}{ Field } & \multicolumn{1}{|c|}{ Type Data } & Size \\
\hline 1 & Id & Int & \\
\hline 2 & Menu_id & Int & 11 \\
\hline 3 & Role_id & Int & 11 \\
\hline
\end{tabular}

5. Tabel User Sub Menu (user_sub_menu) Tabel 7. Penjelasan Tabel user_sub_menu

\begin{tabular}{|c|l|l|c|}
\hline No & \multicolumn{1}{|c|}{ Field } & Type Data & Size \\
\hline 1 & Id & Int & \\
\hline 2 & Menu_id & Int & 11 \\
\hline 3 & Tittle & Varchar & 128 \\
\hline 4 & Url & Varchar & 128 \\
\hline 5 & Icon & Varchar & 128 \\
\hline 6 & Is_active & Int & 1 \\
\hline
\end{tabular}

\section{Tabel Data Prodi (data_prodi)}

Tabel 8. Penjelasan Tabel data prodi

\begin{tabular}{|c|c|c|c|c|c|c|c|c|}
\hline \multicolumn{4}{|c|}{ Tabel 8. Penjelasan Tabel data_prodi } & 11 & \multicolumn{3}{|l|}{ Master_pt_asal } & \multirow{2}{*}{30} \\
\hline No & Field & Type Data & Size & 12 & Master_ahli & Varchar & & \\
\hline 1 & Id & Int & & 17 & Created_at & Timestan & & \\
\hline 2 & Prodi & Varchar & 128 & 18 & Update_at & Timestar & & \\
\hline 3 & Jurusan_dept & Varchar & 128 & \multirow{4}{*}{\multicolumn{4}{|c|}{$\begin{array}{l}\text { Tabel Data Akreditasi Standar } \\
\text { (standar_1) } \\
\text { Tabel 10. Penjelasan Tabel standar_1 }\end{array}$}} & \multirow{7}{*}{1} \\
\hline 4 & Fakultas & Varchar & 128 & & & & & \\
\hline 5 & Perguruan_tinggi & Varchar & 128 & & & & & \\
\hline 6 & No_sk & Varchar & 128 & & & & & \\
\hline 7 & Tgl_sk & Date & & No & Field & Type Data & Size & \\
\hline 8 & Pejabat_penandatangan & Varchar & 128 & 1 & Id & Int & & \\
\hline 9 & Bulan_tahun_ps & Varchar & 128 & 2 & Jawab_1_1_1 & Text & & \\
\hline
\end{tabular}

\begin{tabular}{|c|l|l|c|}
\hline No & \multicolumn{1}{|c|}{ Field } & Type Data & Size \\
\hline 10 & No_operasional & Varchar & 128 \\
\hline 11 & Tgl_operasional & Date & \\
\hline 12 & Peringkat & Varchar & 128 \\
\hline 13 & No_sk_banpt & Varchar & 128 \\
\hline 14 & Alamat & Varchar & 128 \\
\hline 15 & No_telp & Varchar & 128 \\
\hline 16 & Homepage_email & Varchar & 128 \\
\hline 17 & Created_at & Timestamp & \\
\hline 18 & Update_at & Timestamp & \\
\hline
\end{tabular}

7. Tabel Data Dosen (data_dosen)

Tabel 9. Penjelasan Tábel data_dosen

\begin{tabular}{|c|l|l|c|}
\hline No & \multicolumn{1}{|c|}{ Field } & \multicolumn{1}{c|}{ Type Data } & Size \\
\hline 1 & Id & Int & \\
\hline 2 & Nama_dosen & Varchar & 128 \\
\hline 3 & Nidn & Int & 10 \\
\hline 4 & Tgl_lahir & Date & \\
\hline 5 & Jabatan_akademik & Varchar & 128 \\
\hline 6 & Sertifikat & Varchar & 10 \\
\hline 7 & Sarjana_gelar & Varchar & 10 \\
\hline 8 & Sarjana_pt_asal & Varchar & 30 \\
\hline 9 & Sarjana_ahli & Varchar & 30 \\
\hline 10 & Master_gelar & Varchar & 10 \\
\hline 11 & Master_pt_asal & Varchar & 30 \\
\hline 12 & Master_ahli & Varchar & 30 \\
\hline 17 & Created_at & Timestamp & \\
\hline 18 & Update_at & Timestamp & \\
\hline
\end{tabular}

Jika $\mid 61$ 


\begin{tabular}{|c|c|l|l|}
\hline No & Field & Type Data & Size \\
\hline 3 & Jawab_1_1_2 & Text & \\
\hline 4 & Jawab_1_1_3 & Text & \\
\hline 5 & Jawab_1_1_4 & Text & \\
\hline 6 & Jawab_1_1_5 & Text & \\
\hline 7 & Jawab_1_2 & Text & \\
\hline 8 & Date_created & Timestamp & \\
\hline
\end{tabular}

\section{HASIL DAN PEMBAHASAN}

1. Implementation

\section{Tampilan Halaman Registration}

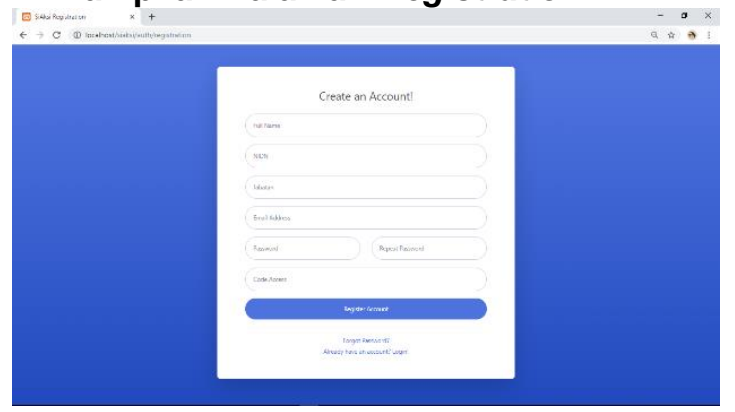

Gambar 5. Tampilan Halaman Registration

\section{Tampilan Halaman Login}

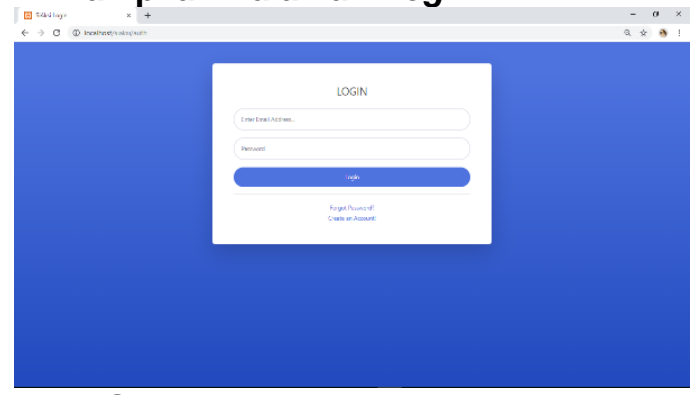

Gambar 6. Tampilan Halaman Login

\section{Tampilan Halaman Menu Utama Admin}

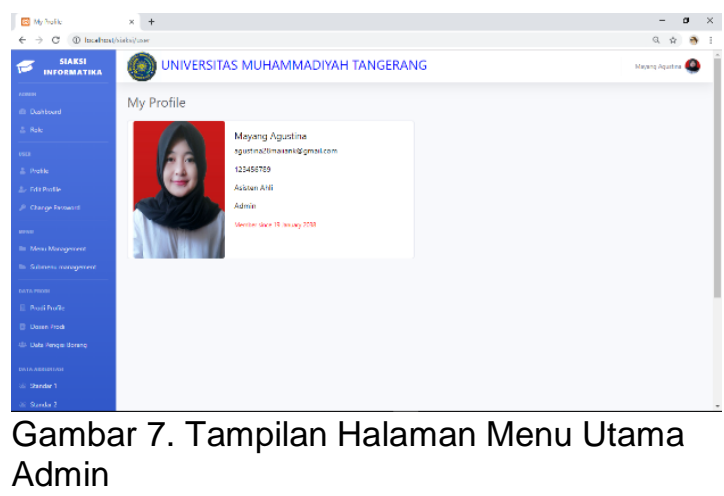

\section{Tampilan Halaman Menu Utama}

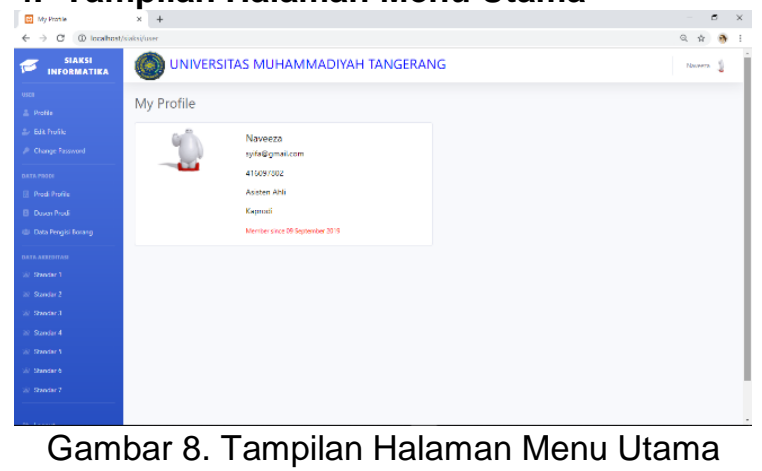

\section{Tampilan Halaman Prodi Profile}

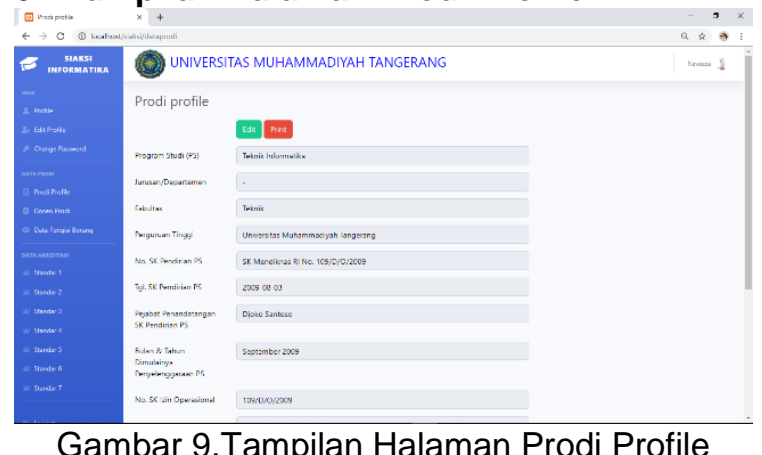

Gambar 9.Tampilan Halaman Prodi Profile 


\section{Tampilan Halaman Dosen Prodi}

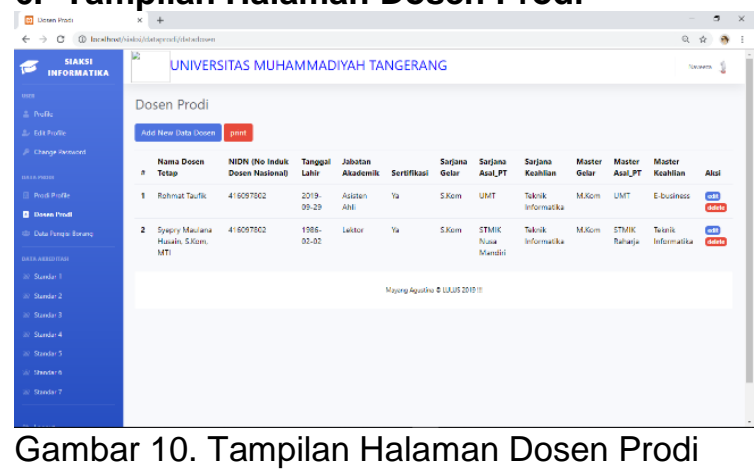

7. Tampilan Halaman Data Pengisi Borang

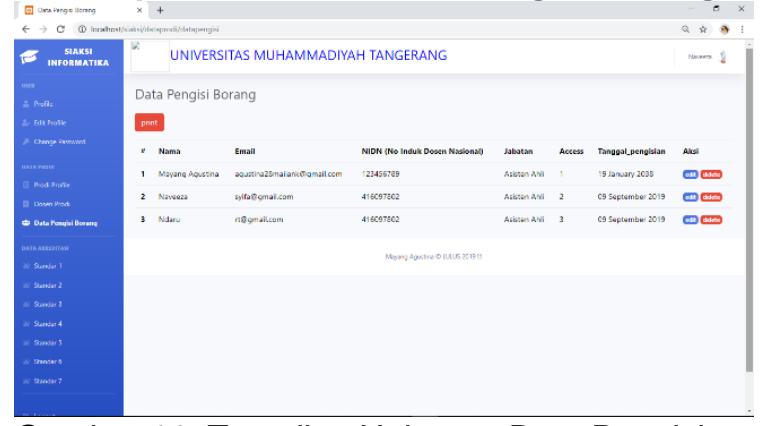

Gambar 11. Tampilan Halaman Data Pengisi Borang

\section{Tampilan Halaman Data Pengisi Borang} Gambar 12. Tampilan Halaman Data Akeditasi

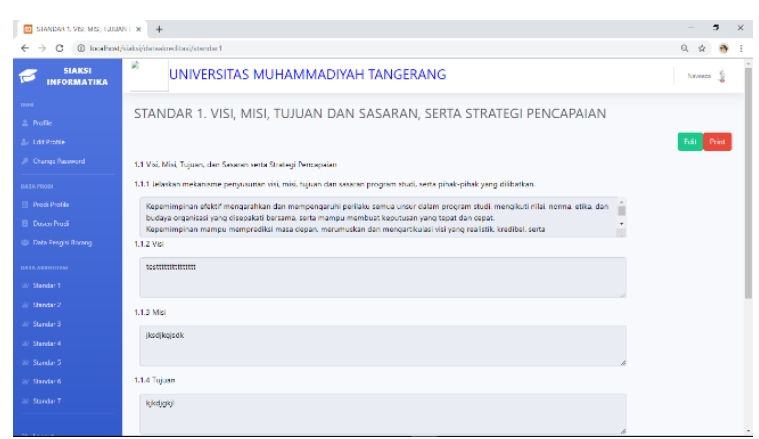

\section{Tampilan Print Out Data Prodi}

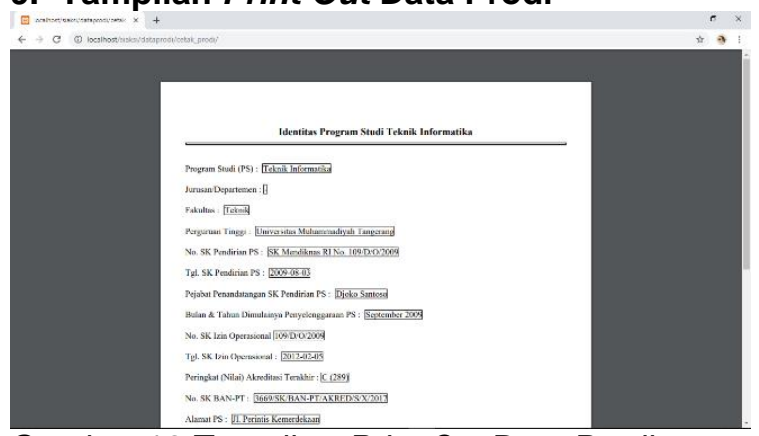

Gambar 12.Tampilan Print Out Data Prodi

10. Tampilan Print Out Data Pengisi Borang

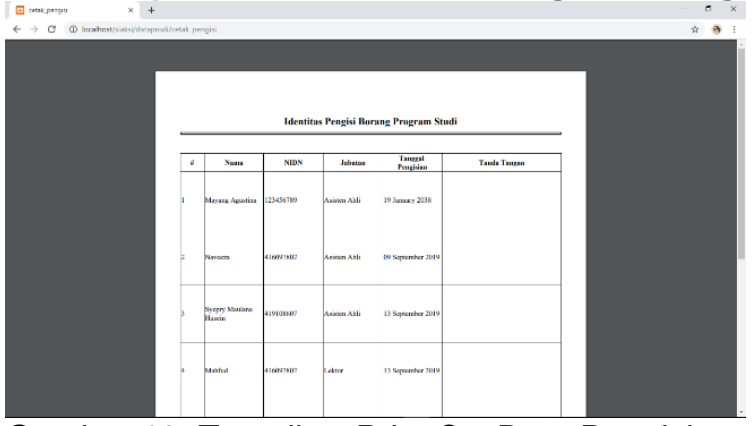

Gambar 13. Tampilan Print Out Data Pengisi Borang

\section{Tampilan Print Out Data Dosen}

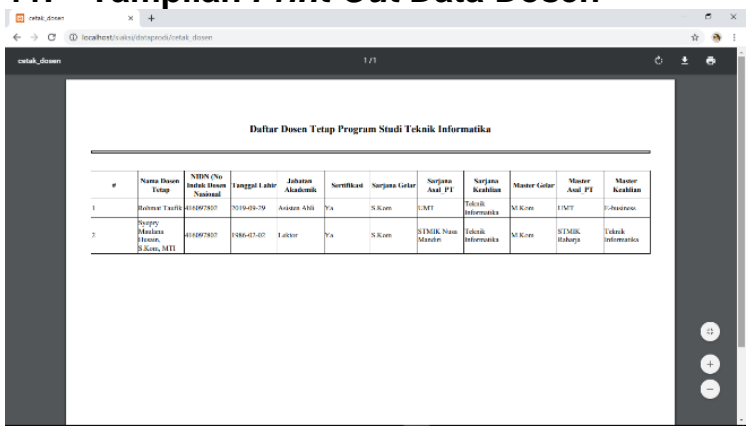

Gambar 14. Tampilan Print Out Data Dosen 


\section{Tampilan Print Out Standar 1}

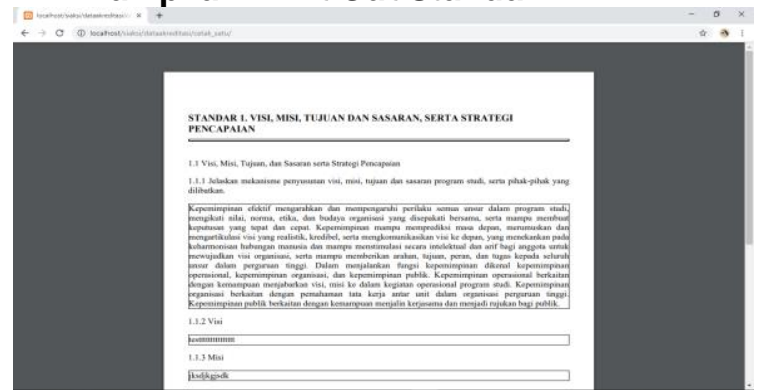

Gambar 15. Tampilan Print Out Standar 1

\section{Tampilan Print Out Standar 2}

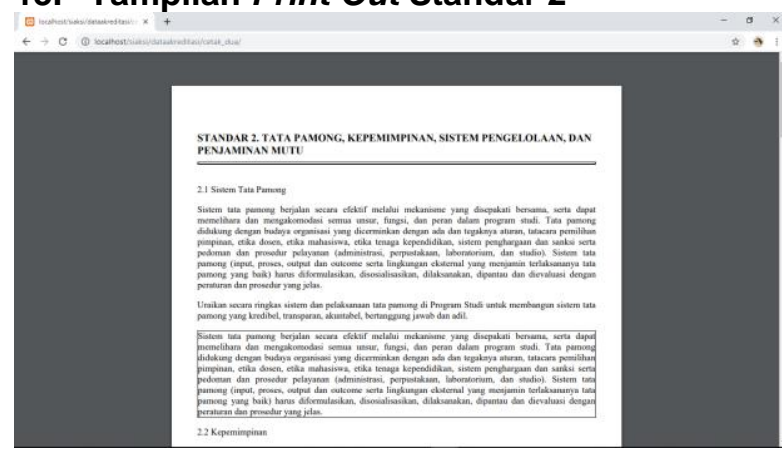

Gambar 16. Tampilan Print Out Standar 2

\section{KESIMPULAN}

Dari hasil penelitian yang telah
dilakukan, maka didapatkan beberapa kesimpulan sebagai berikut :

1. Sistem Informasi Akreditasi Program Studi Teknik Informatika (SiAksi Informatika) telah dapat dibuat dan ditampilkan dalam bentuk website, dengan menggunakan bahasa pemrograman PHP versi 5.6.10, framework Codeigniter, dan penyimpanan data - data borang ke dalam database MySQL dengan user interface yang sangat user friendly.

2. SiAksi Informatika ini memiliki 4 pilihan level user, yaitu sebagai Admin yang dapat melakukan pengelolaan hak akses user dan menu, level Kaprodi yang dapat melakukan pengelolaan tambah, edit, hapus dan cetak pada data prodi, data dosen serta data pengisi borang dan data akreditasi Standar 1 dan 2, level Tim Borang 1 yang dapat mengedit borang Standar 1 dan dapat melihat serta mencetak data prodi, data dosen dan data pengisi borang, level yang terakhir adalah Tim Borang 2 yang dapat mengedit borang Standar 2 dan dapat melihat serta mencetak data prodi, data dosen dan data pengisi borang.
3. Hasil output dari SiAksi Informatika ini berformat pdf yang dapat di download dan print out dalam berbentuk kertas yang dapat dijadikan arsip berkas sebagai bukti ketika visitasi tim asesor.

4. SiAksi Informatika ini dapat digunakan sebagai alternatif dalam memperbaiki proses penyusunan data borang akreditasi yang selama ini berjalan, mulai dari penghematan waktu, memudahkan manajemen dokumen, dan meringankan tugas tim penyusun (tim borang) dalam melakukan penyusunan data - data borang akreditasi.

\section{DAFTAR PUSTAKA}

[1]. Chandra, D D, et al., Sistem Informasi Dokumnetasi Borang Akreditasi Studi Kasus : Program Studi Sistem Informasi Pada STMIK GI MDP, hal 3 .

[2]. Hendini, Ade, 2016, Pemodelan UML Sistem Informasi Monitoring Penjualan Dan Stok Barang (Studi Kasus: Distro Zhezha Pontianak), Jurnal Khatulistiwa Informatika Vol. IV No. 2 Desember 2016, hal 108.

[3]. Kurniawan, R dan Arkan, F. 2016, Rancang Bangun Sistem Borang Akreditasi Program Studi Teknik Elektro Universitas Bangka Belitung, Jurnal Ecotipe ISSN 2355-5068 Volume 3, Nomor 2, hal 32.

[4]. Download - Pengertian Program Studi dan Akreditasi Program Studi Sarjana - Rabu, 3 Juli 2019 http://luk.staff.ugm.ac.id/atur/ban/s1/Bu ku 1- Naskah Akademik Akreditasi Program Studi Sariana.doc

[5]. Siregar, S R, dan Sundari, P. 2016, Rancangan Sistem Informasi Pengelolaan Data Kependudukan Desa (Studi Kasus di Kantor Desa Sangiang Kecamatan Sepatan Timur, Jurnal Sisfotek Global Vol. 6 No. 1 ISSN :2088 - 1762 Maret 2016, hal 77. 